DOI: https://doi.org/10.31392/NZ-npu-142.2019.11

УДК $37.091 .33: 811.111$

Качанов В. І., Кодалашвілі О. Б.

\title{
СУЧАСНІ МЕТОДИЧНІ ПІДХОДИ ДО ВИКЛАДАННЯ АНГЛІЙСЬКОї МОВИ
}

У статті розглянуто сучасні методичні підходи щзодо вивчення англійської мови. Наголомено на ролі англійської мови в процесі глобалізації. Проведено аналіз сучасних методичних підходів щзодо розвитку вмінь та навичок англійської мови з основних видів мовленнєвої діяльності (читання, говоріння, аудіювання та письма), а також їх переваг $i$ недоліків. Особливу увагу приділено проведенню занять з використанням комунікативного підходу, за допомогою дистанційних засобів навчання та сучасних інформаційних технологій. Визначено напрямки подальших перспективних досліджень.

Англійська мова стає важливим фактором майбутніх перспектив робітників щодо працевлаштування, кар 'єрного зростання, ведення і розвитку бізнесу.

Водночас постійно зростаючі потреби у здійсненні іншомовної комунікації англійською мовою, як мовою міжнародного спілкування, викликали потребу в удосконалені існуючих $i$ використанні нових підходів у процесі навчання англійської мови.

У статті визначено напрямки подальших перспективних досліджень з метою підвищення якості та ефективності ї̈ викладання.

Сучасні інформачійні технологї сприяють розвитку вмінь та навичок з читання, які можна покрашувати як за допомогою виконання навчальних завдань з читання за допомогою онлайнресурсів, так і читанням автентичної літератури, засобів масової інформачії аналійською мовою, тощо.

Вибір методу навчання англійської мови (або їх комбінаціi), переважно залежить від мети навчання. Глобалізація всіх сфер життєдіяльності, розвиток Інтернету та сучасних засобів інформатизачї спричинили виникнення і бурхливий розвиток нових підходів до вивчення англійської мови, зокрема комунікативного підходу, дистаниійного методу навчання та використання інформаційних технологій, які потребують подальшого дослідження.

Ключові слова: сучасні методичні підходи, викладання англійської мови, комунікативний підхід, вміння та навички з англійської мови, дистанційне навчання, иільова мова, платформа дистаниійного навчання Moodle, Skype.

Роль англійської мови у світі постійно зростала впродовж останніх десятиліть, що було спричинено світовою глобалізацією в усіх сфрерах життєдіяльності і як наслідок - зростанням потреби у здійсненні іншомовної комунікації [1, с. 2].

Відповідно до дослідження, проведеного Британською Радою в 2013 році, англійською мовою розмовляють 1,75 млрд людей в усьому світі. Це означає, що кожен четвертий житель на планеті використовує англійську мову. Дослідники прогнозують, що до 2020 року 2 млрд людей будуть вчити чи використовувати англійську мову [1, с. 2]. При цьому, в дослідженні підкреслюється, що співвідношення не носіїв мови, які її використовують, до носіїв мови у 2013 році становила 4:1, і тенденція на збільшення цього співвідношення буде продовжуватися [1, с. 4].

Англійська мова зробила суттєвий внесок у стійкий глобальний розвиток 
міжнародних відносин [1, с. 2]:

- сприяє полегшенню торгівлі та розвитку економічних відносин між країнами;

- використовується для розвитку діалогу і створення довіри під час вирішення проблем міжнародних відносин, особливо що стосується проведення миротворчих операцій і вирішення міжнародних конфлліктів, коли миротворці з різних країн спілкуються англійською мовою;

- використовується міжнародними організаціями під час розгляду важливих питань для майбутнього розвитку людства, а саме кліматичних змін, проблем міжнародного тероризму та дотримання прав людини.

Вплив глобалізації та економічного розвитку зробили англійську мову важливим фактором на ринку праці. Так, у доповіді відзначається, що більшість роботодавців заявили, що для зростання і розширення їхнього бізнесу їхні робітники повинні володіти англійською мовою, при цьому четверта частина керівників наголосили, що відсоток працівників, які володіють англійською мовою, повинен становити більше ніж 50\%. Відповідно англійська мова стає важливим фактором майбутніх перспектив робітників щодо працевлаштування, кар'єрного зростання, ведення і розвитку бізнесу [1, с. 2].

Водночас постійно зростаючі потреби у здійсненні іншомовної комунікації англійською мовою, як мовою міжнародного спілкування, викликали потребу в удосконалені існуючих і використанні нових підходів у процесі навчання англійської мови.

В Україні питання методики викладання іноземної мови були розглянуті в роботах С. Ю. Ніколаєвої $[2,3]$. Так, у цих дослідженнях було проведено огляд методів навчання іноземних мов та наведено їх класифікацію $[2,3]$. Особлива увага була приділена аналізу перекладних, прямих, усних, аудіолінгвальних, аудіовізуальних, сугестивних, комунікативних та інших методів навчання іноземних мов [2, 3]. Також велика увага в працях С. Ю. Ніколаєвої приділена як теоретичним основам, так і практичному застосуванню різних методичних підходів в процесі навчання іншомовної компетенції [2, 3]. Так, наприклад, ретельно досліджуються питання формування іншомовної компетенції (навчання граматичному, лексичному та фонетичному матеріалу) та мовленнєвої компетенції (навчання аудіюванню, говорінню, читанню та письму) $[2,3]$.

При цьому питання дистанційного навчання іноземної мови, яке набуває особливої актуальності в сучасному глобалізованому світі, також як і питання вибору методів навчання, потребують подальшого дослідження.

Метою cmammi $\epsilon$ аналіз сучасних методичних підходів до викладання англійської мови, а також визначення напрямків подальших перспективних досліджень з метою підвищення якості та ефективності її викладання.

Необхідно зауважити, що існують різні підходи до класифікації методів викладання англійської мови, але найбільш поширеними в той чи інший період часу були [2-5]:

- граматико-перекладний;

- комунікативний;

- дистанційний.

Граматико-перекладний метод є різновидом класичного (традиційного) 
методу, основою якого є вивчення граматичних правил та їх застосування під час двостороннього перекладу з цільової на рідну мову і навпаки. Цілями цього методу навчання іншомовної компетенції $\epsilon$ : вчити студентів читати і перекладати з цільової мови на рідну мову і навпаки, а також покращити загальний освітній рівень студентів [5]. При цьому необхідно зауважити, що використання граматико-перекладного методу не забезпечує повною мірою відповідності сучасним вимогам до вивчення іноземних мов, однією 3 найголовніших з яких $€$ успішне здійснення акту мовленнєвої комунікації цільовою (англійською) мовою [5].

Одним із найбільш поширених серед сучасних методів навчання $\epsilon$ комунікативний підхід. Комунікативне навчання англійської мови (комунікативний метод) - це метод навчання, який розглядає використання мовленнєвої комунікації одночасно як основний засіб і мету навчання [6-12]. Він $€$ одним 3 найбільш сучасних і популярних методів навчання іншомовної компетенції. Метою комунікативного підходу, на відміну від лексикограматичного методу, в якому головний пріоритет надається навчанню граматичної компетенції, $\epsilon$ формування у студентів вмінь та навичок здійснювати мовленнєву комунікацію цільовою (англійською) мовою [10].

Велика увага питанням застосування комунікативного методу навчання іншомовної компетенції приділена в роботах С. Ю. Ніколаєвої $[2,3]$. Вона дає визначення комунікативної компетенції як “...вміння успішно вирішувати завдання взаєморозуміння з носіями мови, яка вивчається відповідно до норм і культурних традицій в умовах прямого і опосередкованого контактів" [2, с. 33]. Зауважується, що реалізація “... комунікативного підходу у навчальному процесі означає, що оволодіння засобами спілкування (фонетичними, лексичними, граматичними) спрямоване на їх практичне застосування у процесі спілкування. Оволодіння уміннями говоріння, аудіювання, читання та письма здійснюється шляхом реалізації цих видів мовленнєвої діяльності у процесі навчання в умовах, що моделюють умови реального спілкування" [3, с. 39].

3 метою реалізації комунікативного підходу в процесі навчання іншомовної компетенції використовуються наступні форми і способи [10]:

- рольові ігри;

- інтерв'ю;

- робота в парах та міні групах;

- вправи на заповнення пропусків;

- обґрунтування своєї думки;

- вільне спілкування між студентами.

Розвиток вмінь та навичок 3 говоріння відбувається 3 використанням роботи в міні-групах та парах, що стало характерною рисою комунікативного підходу [4, с. 87]. Такий спосіб навчання, порівняно з груповою фрормою проведення занять, суттєво збільшує кількість часу, яку кожен студент може використати для відпрацювання навичок з говоріння [4, с. 87]. Крім того, працюючи в міні-групах або в парах, студенти менше хвилюються, ніж виступаючи перед великою групою, що також сприяє розвитку швидкості англійської розмовної мови [4, с. 87]. Основним завданням викладача під час такої форми навчального заняття $€$ здійснення контролю та допомога студентам [4, с. 87]. Обговорення певної теми також сприяє розвитку навичок 3 
говоріння. Для такої фрорми навчальної роботи, наприклад, можуть використовуватися такі завдання [4, с. 87]:

- знайдіть десять відмінностей між двома малюнками;

- розташуйте в порядку пріоритету набір певних характеристик;

- сплануйте вечірку;

- та інші.

Основною метою застосування комунікативного підходу в читанні $\epsilon$ розвиток навичок читання англійською мовою як одного 3 основних видів мовленнєвої діяльності, що сприяє успішному здійсненню акту іншомовної комунікації [4, с. 83]. 3 цією метою під час відпрацювання вмінь та навичок 3 читання процес читання тексту розбивається на три етапи: завдання, які виконуються перед читанням тексту ("pre-reading" task); завдання, які виконуються в процесі читання (“while-reading" task) та завдання, які виконуються після прочитання тексту ("post-reading" task) [4, с. 83].

Основною метою завдань, які виконуються перед читанням тексту ("prereading" task), є допомога студентам у покращенні їх обізнаності щодо того матеріалу, який вони збираються читати на занятті. Завдяки цьому завданню у студентів покращується загальне розуміння прочитаного тексту [4, с. 83].

Основним завданням у процесі читання ("while-reading" task) $є$ покращення рівня усвідомлення прочитаного матеріалу. Це досягається завдяки роботі в міні-групах та поділу тексту на частини, коли кожен студент читає лише свою частину тексту. Основною перевагою такого типу завдань $€$ їх комунікативна спрямованість. Зміст завдання полягає в тому, що під час такого типу діяльності студенти, для повного розуміння тексту, повинні працювати спільно, ставлячи питання своїм партнерам у міні-групі та відповідаючи на їх питання [4, C. 83].

Завдання в процесі читання ("while-reading" task) поступово переходять на етап виконання завдань після прочитання тексту ("post-reading" task), які полягають у:

- обговоренні прочитаного тексту в групі, міні-групах або в парах;

- узагальненні прочитаного;

- рецензуванні тексту;

- виконанні наступних завдань з говоріння, які базуються на матеріалах прочитаного тексту, або пов'язані з ним;

- повторенні та закріпленні нової лексики, яка використовувалася в тексті (поясненні значення нових слів (виразів) англійською мовою, співставлення нових слів (виразів) та їх значень ("matching task")) [4, с. 83].

Також ефективним методичним прийомом щодо покращення мовленнєвої компетенції з читання $€$ повторне читання базового тексту для розділу в підручнику [4, с. 83]. По-перше, повторне читання тексту сприяє кращому розумінню прочитаного матеріалу, а по-друге, допомагає студентам зрозуміти лексику, виходячи з контексту, що покращує ефективність навчання і сприяє покращенню швидкості читання [4, с. 83].

Читацький театр (“R eader's theater") - один з нових підходів щодо розвитку мовленнєвої компетенції з читання і говоріння за допомогою участі студентів у виставі [4, с. 83]. Суть методу полягає у виразному читанні вголос ролі у виставі без вивчення слів на пам'ять, без костюмів та сцени. 3 цією метою 
студенти розподіляються на міні-групи (залежно від кількості персонажів у виставі) і читають свої слова виразно, інтерпретуючи роль відповідно до персонального бачення, використовуючи мову тіла, міміку і жести. Крім того, студенти, граючи у виставі, яка базується на культурі та історії країни, мова якої вивчається, ознайомлюються з ними, або поглиблюють свої знання щодо цих важливих елементів вивчення іноземної мови [4, с. 83].

3 метою покращення комунікативної спрямованості під час відпрацювання вмінь та навичок з аудіювання доцільно використовувати не лише аудіо-, а й відеоматеріали, адже процес реальної іншомовної комунікації в більшості випадків передбачає спілкування зі співрозмовником обличчя до обличчя $[4, \mathrm{c}$. 70].

Сучасні інформаційні технології сприяють збільшенню комунікативної спрямованості під час розвитку навичок з письма. Так, наприклад листування 3 англомовними друзями за допомогою соціальних мереж або інших сучасних інформаційних технологій - це здійснення акту реальної іншомовної комунікації цільовою (англійською) мовою, що суттєво сприяє розвитку мовленнєвої компетенції з письма [4, с. 70].

Одним з основних недоліків комунікативного підходу визначають його комунікативну спрямованість, яка одночасно є його найбільшою перевагою, що в деяких випадках може привести до недостатнього знання фрормальних аспектів мови, а саме граматики. І, як наслідок - невміння правильно використовувати граматичні конструкції для здійснення іншомовної комунікації цільовою (англійською) мовою [9, 10].

Дистанційне навчання відкриває нові можливості в навчанні англійської мови [12]. Перевагами дистанційного способу навчання є:

- мобільність (можливість навчатися незалежно від місця перебування та часу);

- можливість приділяти більшу увагу кожному студенту;

- створення інтерактивного навчального середовища.

Основними сучасними інформаційними технологіями, які дають можливість дистанційно навчати англійської мови $є$ Skype, платфрорма дистанційного навчання Moodle, соціальні мережі та інші [12].

Безсумнівними перевагами дистанційного навчання за допомогою Skype $\epsilon$ можливість організовувати процес безперервного навчання, незалежно від місця розташування викладача і студентів, та різниці в часі. А завдяки можливостям здійснення відеозв'язку, процес навчання $\epsilon$ інтерактивним і комунікативним, забезпечуючи необхідну якість навчального процесу, що $\epsilon$ надзвичайно важливим в умовах сучасного глобалізованого, мобільного світу. Одним з основних недоліків Skyре $€$ обмежені можливості щодо кількості студентів, які можуть навчатися одночасно, внаслідок чого цей спосіб дистанційного навчання може використовуватися лише для малочисельних груп студентів [12]. Але при цьому, необхідно зауважити, що суттєвою перевагою навчання англійської мови в міні групах є можливість для викладача приділяти більше уваги кожному студенту [12].

Платформа дистанційного навчання Moodle може використовуватися як додатковий елемент між он-лайн сесіями. Вона забезпечує можливість здійснення викладачем он-лайн обговорення зі студентами навчальних 
матеріалів, ставити питання та отримувати відповіді, розміщувати необхідні навчальні матеріали та забезпечувати доступ до них студентів у визначений час, організовувати самостійну роботу, проводити поточний та підсумковий контроль знань [12].

Бурхливий розвиток інформаційних технологій суттєво впливає на процес набуття іншомовної компетенції. Так, мобільні телефони та планшети забезпечують додаткові можливості у вивченні іноземних мов загалом та англійської мови зокрема. Перевагами їх використання $€$ мобільність, інтерактивність, можливість здійснення відеозв'язку, використання он-лайн ресурсів для покращення мовленнєвих навичок 3 усіх основних видів мовленнєвої діяльності: говоріння, читання, аудіювання та письма [13]. Також сучасні мобільні телефони та планшети дають можливість студентам створювати своє навчальне середовище: фотографувати вивіски та надписи англійською мовою, зберігати текстові, відео- та аудіо- навчальні матеріали 3 основних видів мовленнєвої діяльності [13]. Так, наприклад, для покращення вмінь та навичок з говоріння можуть використовуватися наступні засоби: сучасні електронні словники, які дають можливість перевіряти правильність вимови слів цільовою (англійською) мовою; мобільні додатки та програми, які дають можливість студентам створювати свої власні словники, додавати вибрані ними слова і забезпечують їх періодичне повторення; можливості онлайн спілкування з носіями мови, або використання великої кількості навчальних он-лайн ресурсів зі зразками мовлення носіїв мови за рівнями володіння іноземною мовою та відповідним тематичним розподілом [13]. Для покращення вмінь та навичок з аудіювання сучасні цифрові технології також забезпечують широкі можливості, наприклад використання великої кількості навчальних он-лайн ресурсів зі зразками мовлення носіїв мови різних рівнів та завданнями до них [13]. Можливості переглядати он-лайн телевізійні програми, фільми, слухати пісні англійською мовою - всі ці заходи сприяють розвитку вмінь та навичок з аудіювання. Сучасні інформаційні технології сприяють також розвитку вмінь та навичок з читання, які можна покращувати як за допомогою виконання навчальних завдань з читання за допомогою он-лайн ресурсів, так i читанням автентичної літератури, засобів масової інформації англійською мовою, тощо [13]. Розвиток навичок з письма забезпечується як використанням навчальних он-лайн ресурсів зі зразками різних видів письмових робіт, так і можливістю реального листування з носіями мови або англомовними друзями (колегами) [13].

Для викладачів англійської мови використання мобільних пристроїв також відкриває широкий спектр можливостей [13]:

- використання мобільних додатків для створення групових чатів;

- можливість швидко створювати різні види навчальних матеріалів (текстових, аудіо-, відео- та ін.) та ділитися ними зі студентами;

- робити посилання на різні види он-лайн ресурсів;

- організовувати обговорення навчальних матеріалів.

Отже, необхідно зауважити, що вибір методу навчання англійської мови (або їх комбінації), переважно залежить від мети навчання. Глобалізація всіх сорер життєдіяльності, розвиток Інтернету та сучасних засобів інформатизації, спричинили виникнення і бурхливий розвиток нових підходів до вивчення 
англійської мови, зокрема комунікативного підходу, дистанційного методу навчання та використання інформаційних технологій, які потребують подальшого дослідження.

\section{Використана література:}

1. [Electronic resource]. Regime of access : https://www.britishcouncil.org/sites/default/files/english-effectreport-v2.pdf.

2. Ніколаєва С. Ю. Основи сучасної методики викладання іноземної мови. Київ : Ленвіт, 2008. 285 с.

3. Методика викладання іноземних мов у середніх навчальних закладах: підручник / С. Ю. Ніколаєва, О. Б. Бігич, Н. О. Бражник [та ін.]. Київ : Ленвіт, 2002. 328 с.

4. Penny U r's 100 Teaching tips. Cambridge : Cambridge U niversity Press, 2016. $131 \mathrm{p}$.

5. [Electronic resource]. Regime of access : https://en.wikipedia.org/wiki/L anguage_pedagogy.

6. [Electronic resource]. Regime of access: http://ontesolteacherscorner.com/CommunicativeTasks A ndT hel anguageC urriculum.pdf.

7. [Electronic resource]. Regime of access: https://static.cambridge.org/resource/id/urn:cambridge.org: id:binary:20170224075738467-0497:S0272263198234061:S027226319800406X a.pdf.

8. B ax S. The end of CLT: a context approach to language teaching. ELT J ournal. 2003. P. 278-287.

9. [Electronic resource]. Regime of access: https://www.teachingenglish.org.uk/sites/teacheng/files /F044\%20EL T-44\%20The\%20Practice\%20of\%20Communicative\%20T eaching_v3.pdf.

10. [Electronic resource]. Regime of access: https://en.wikipedia.org/wiki/Communicative_language teaching.

11. [Electronic resource]. Regime of access : http://seas3.elte.hu/coursematerial/HalapiM agdolna/Swan2.pdf.

12. [Electronic resource]. Regime of access: https://www.britishcouncil.org/voices-magazine/teachingenglish-online-opportunities-pitfalls.

13. [Electronic resource]. Regime of access : https://www.britishcouncil.org/voices-magazine/teaching-tipshow-students-can-use-mobiles-to-learn-english.

\section{Ref erences:}

[1] [Electronic resource]. Regime of access : https://www.britishcouncil.org/sites/default/files/english-effectreport-v2.pdf.

[2] Nikolaieva S. lu. (2008). Osnovy suchasnoi metodyky vykladannia inozemnoi movy. Kyiv: Lenvit. $285 \mathrm{~s}$.

[3] Metodyka vykladannia inozemnykh mov u serednikh navchalnykh zakladakh: pidruchnyk / S. Iu. Nikolaieva, O. B. Bihych, N. O. Brazhnyk [ta in.]. K yiv : Lenvit, 2002. 328 s.

[4] (2016). Penny Urs 100 Teaching tips. Cambridge: Cambridge U niversity Press. - $131 \mathrm{p}$.

[5] [Electronic resource]. Regime of access : https://en.wikipedia.org/wiki/L anguage_pedagogy.

[6] [Electronic resource]. Regime of access: http://ontesolteacherscorner.com/CommunicativeTasks A ndT heL anguageC urriculum.pdf.

[7] [Electronic resource]. Regime of access: https://static.cambridge.org/resource/id/urn:cambridge.org: id:binary:20170224075738467-0497:S0272263198234061:S027226319800406X a.pdf.

[8] Bax S. The end of CLT: a context approach to language teaching. ELT J ournal. 2003. P. 278-287.

[9] [Electronic resource]. Regime of access: https://www.teachingenglish.org.uk/sites/teacheng /files/F044\%20ELT-44\%20The\%20Practice\%20of\%20C ommunicative\%20T eaching_v3.pdf.

[10] [Electronic resource]. Regime of access: https://en.wikipedia.org/wiki/Communicative_language teaching.

[11] [Electronic resource]. R egime of access : http://seas3.elte.hu/coursematerial/H alapiM agdolna/Swan2.pdf.

[12] [Electronic resource]. Regime of access: https://www.britishcouncil.org/voices-magazine/teachingenglish-online-opportunities-pitfalls.

[13] [Electronic resource]. Regime of access : https://www.britishcouncil.org/voices-magazine/teaching-tipshow-students-can-use-mobiles-to-learn-english. 


\section{КАЧАНОВ В. И., КОДАЛАШВИЛИ О. Б. Современные подходы в ИзУчении английского языка.}

В статье рассмотрены современные методические приемы по изучению английского языка. Отмечена роль английского языка в прочессе глобализации. Проведен анализ современных методических приемов по развитию умений и навыков английского языка по основным видам деятельности (чтения, говорения, аудирования и письма), а также их преимуществ и недостатков. Особое внимание обращено на использование коммуникативного метода изучения иностранных языков, дистанционное обучение, а также на информационные технологии. Проведен анализ современных методических приемов по изучению английского языка, рассмотрены их преимущества и недостатки, определены направления последующих перспективных исследований.

Английский язык становится важным фактором будущих перспектив работников по трудоустройству, карьерному росту, ведению и развитию бизнеса. В то же время постоянно растущие потребности в осуществлении иноязычной коммуникаџии на английском языке, как языке международного общения, вызвали необходимость усовершенствования существуюших и использования новых подходов в проиессе обучения английскому языку.

В статье определень направления дальнейших перспективных исследований с иелью повышения качества и эффективности его преподавания.

Современные информаџионные технологии способствуют развитию умений и навыков чтения, которые можно улучшать как с помощью выполнения учебных заданий по чтению с помощьью онлайн-ресурсов, так и чтением аутентичной литературы, средств массовой информации на английском языке, и тому подобное.

Выбор метода обучения английскому языку (или их комбинации) преимущественно зависит от иели обучения. Глобализащия всех сфер жизнедеятельности, развитие интернета и современных средств информатизаџии вызвали возникновение и бурное развитие новых подходов $\kappa$ изучению английского языка, в частности коммуникативного подхода, дистанционного метода обучения и использования информаџионных технологий, требуюших дальнейтего исследования.

Ключевые слова: современные методические приемы для изучения английского языка, преподавание английского языка, коммуникативный метод, дистанционное обучение, язык изучения, современные информационные технологии, платформа дистанционного обучения Moodle, Skype.

KACHANOV V. I., KODALASHVILI O. B. Modern approaches in teaching english language.

In the article modern approaches in teaching English language are studied. The role of English language in Globalization is stressed. The main approaches in developing English language reading, speaking, listening and writing skills are analysed. The advantages and disadvantages of modern approaches in teaching English language are considered. Particular attention is paid to communicative approach, distance learning, and using information technology. The main approaches to further studies are considered.

Angliyskiy yazyk stanovitsya vazhnym faktorom budushchikh perspektiv rabotnikov po trudoustroystvu, kar'yernomu rostu, vedeniyu i razvitiyu biznesa. $V$ to zhe vremya postoyanno rastushchiye potrebnosti $v$ osushchestvlenii inoyazychnoy kommunikatsii na angliyskom yazyke, kak yazyke mezhdunarodnogo obshcheniya, vyzvali neobkhodimost' usovershenstvovaniya sushchestvuyushchikh i ispol'zovaniya novykh podkhodov v protsesse obucheniya angliyskomu yazyku.

V stat'ye opredeleny napravleniya dal'neyshikh perspektivnykh issledovaniy s tsel'yu povysheniya kachestva i effektivnosti yego prepodavaniya. Sovremennyye informatsionnyye tekhnologii sposobstvuyut razvitiyu umeniy i navykov chteniya, kotoryye mozhno uluchshat' kak s pomoshch'yu vypolneniya uchebnykh zadaniy po chteniyu s pomoshch'yu onlayn-resursov, tak i chteniyem autentichnoy literatury, sredstv massovoy informatsii na angliyskom yazyke, i tomu podobnoye. Vybor metoda obucheniya angliyskomu yazyku (ili ikh kombinatsii) preimushchestvenno zavisit ot tseli obucheniya. Globalizatsiya vsekh sfer zhiznedeyatel'nosti, razvitiye interneta i sovremennykh sredstv informatizatsii vyzvali vozniknoveniye i burnoye razvitiye novykh podkhodov k izucheniyu angliyskogo 
yazyka, $v$ chastnosti kommunikativnogo podkhoda, distantsionnogo metoda obucheniya i ispol'zovaniya informatsionnykh tekhnologiy, trebuyushchikh dal'neyshego issledovaniya.

Keywords: modern approaches in teaching English, communicative approach, distance learning, target language, modern information technology, learning management system M oodle, Skype.

DOI: https://doi.org/10.31392/NZ-npu-142.2019.12

УДК 378.1(1-87).001.86:614.2:615

Клос Л. М.

\section{ТЕНДЕНЦІЇ ПРОФЕСІЙНОї ПІДГОТОВКИ ФАХІВЦІВ ФАРМАЦЕВТИЧНОЇ ГАЛУЗІ: ЗАРУБІЖНИЙ ДОСВІД}

У статті охарактеризовано потреби та вимоги до фармацевтичної освіти в Україні; проаналізовано актуальні проблеми забезпечення європейських стандартів фармацевтичної освіти в Україні; узагальнено зарубіжний досвід із забезпечення якості та неперервності вищої фармацевтичної освіти; розкрито практичні здобутки з фармацевтичної підготовки на прикладі деяких провідних європейський освітніх закладів. Зроблено висновки про можливість запозичення деяких аспектів зарубіжного досвіду у процес підготовки фармачевтів у вивченні мікробіології, вірусології та імунологї.

Ретельно досліджено зарубіжний досвід професійної підготовки фахівиів фармачевтичної галузі, виокремлено провідні тендениії та теоретично обгрунтувано можливість відповідного оновлення системи підготовки фахівиів фармацевтичної галузі в Украйні.

Для всіх закладів освіти різних країн, які займаються підготовкою фармачевтів, за широкого різноманіття вимог до їх професійної діяльності, $\epsilon$ спільний чинник впливу на якість та доступність освіти - певний вибір форми навчання - традиційної (очноі) та дистанційної. 3 огляду на це необхідним зазначити, щуо змістове наповнення фармацевтичної освіти, описи, структура $\epsilon$ доступними для студентів на відповідних веб-ресурсах, тобто для використання на відстані.

Студенти отримують можливість навчатися у зручний для них час, незалежно від їхнього місцеперебування. Вони можуть перервати освітній прочес за особистих обставин, щзо складаються, та за потреби повернутися до нього. Курс навчання надає можливість взаємодіяти з висококваліфікованими та досвідченими професіоналами та в них навчатися.

Описаний зарубіжний досвід актуалізує завдання та напрями реорганізаиії традиційної системи підготовки фармачевтів в Украйні. Головна ідея полягає в створенні моделі системи освіти, що буде спрямована на забезпечення кожному можливості отримання та поповнення знань, фаховий розвиток, вдосконалення та професійну самореалізацію протягом усього життя.

Ключові слова: фармацевт, освіта, підготовка, освітній заклад, мікробіологія, вірусологія, імунологія, неперервність, дистаниійне навчання.

Стратегія нашої держави останніми роками спрямовується на неперервну трансорормацію та входження до світової освітньої громади. Інтеграційні процеси у напрямі входження України до європейського простору, розвиток технологій та освіти останнім часом потребують перегляду та оновлення процесу підготовки фахівців різних галузей. Адже їх професійний рівень повинен бути ідентичним тенденціям, які спостерігаються в суспільстві. Вагомим складником системи освіти нашої держави $є$ вища фрармацевтична 